\title{
新潟紧の海鳥慜死に関する考察
}

千 羽 晋 示*

このところ日本各地で, 海鳥類の大量嫳死が相次いで発見されているようである。新潟県で も，ここ数年海鳥の整死現象が見られ，中には貴重な発胃や記録が含まれている。新潟県の海 鳥類については，まだそれのみをとりあげたものはないが，綜合的な報告の中に含まれて，い くつか報ぜられている。古くは中村正雄(1925)にはじまり, 石沢慈鳥(1956), 千羽元一(1955) 千羽晋示(1961)などがある。

このたび，これまでの記録をもとに海鳥類の一部（ミッ゙ナギドリ科，アビ科，カモメ科，卜 ウゾクカモメ科, ウミスズメ科）の 5 科 28 種について, 冬季の分布海面の推定, また斃死の原 因などの考察をして見たい。

\section{新潟県の海鳥記 録}

Procellariidae ミッ゙ナギドリ科

1) Fulmarus glacialis rodgersii フルマカモメ

XI, 1920 柏崎; I, 1936 村上

2) Pterodroma hypoleuca シロ八ラミッ゙ナギドリ

17 X, 1956 柏崎市裏浜海岸（令成）；VII，1958 柏崎帊岬町；29 IX, 1959 杤尾市

3) Puffinus carneipes アカアシミヅナギドリ

23 IV, 1959 新港外

4) Calonectris leucomelas オオミヅナギドリ

4 XII，1948，14 XI，1951 長㫦帊；5 V，1958 采帠；15 IV，1960 新潟市松波町；18 III，1962 柏崎市裏浜海岸 (合成)；4 III，1964 柏崎市椎谷 ( P)

\section{Gaviidae アビ 科}

1) Gavia arctica viridigularis オオ八ム

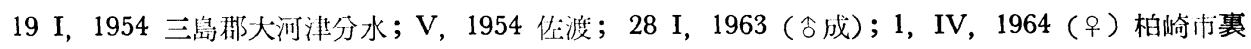
浜海竫

2) Gavia arctica pacificaシロエリオオ八ム

IV, 1954 佐渡耐津

3) Gavia stellata アビ

19 I, 1954 三島郡大河津分水; III, 1959 位渡, 22 III, 1961 柏猗市鏡町 (早成)；9 III，1963 柏

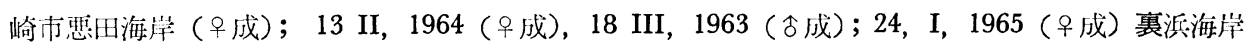

\section{Laridae カモメ科}

1) T'halasseus bergii cristatus オオアジサシ

新潟県天産志に出典，不㳄によればアジサシの毁りなるべしとあり。

2) Sterna hirundo longipennis アジサシ

* 束京都港区芝白金台町 目立科学博物館附掘自然教育国 
9 VI, 1951 三島郡与板町, 28 IV, 1954 新潟港外

3) S. albifrons sinensis コアジサシ

例年 4 月頃から県内各地の湖沼，河川，田圃などに飛来する。9 月頃まで見られる。

4) Rissa tridactyla pollicaris ミツュビカモメ 23 XI, 1961 西蒲原郡粟生津 (우成), 16 XI, 1964 (古幼), 23 III, 1965 ( 4 倜休)， 26 III,

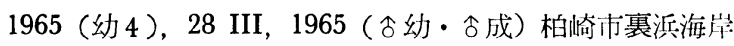

5) Larus argentatus vegae セグロカモメ

7 I, 1955 三島郡大河津分水, 23 III，1956 柏崎市，IV， 1956 佐渡

6) Larus schistisagus オオセグロカモメ

26 IV, 1953 柏崎市；I，1958 佐渡；21 XII, 1962 柏崎市裏浜海牢 (早成)；28 III, 1963 柏崎 市悪田海岸 ( 9 幼)

7) Larus canus kamtschatschensis カモメ

II, 1957 佐渡；23 III，1962 柏崎市裏浜海岸 (合成)；16 IV, 1963 柏崎市悪田海岸 (早成)；６ I, 1965 (ㅇ成)；26 III， 1965 柏崎市裏浜海岸

8) Larus crassirostris ウミネコ

29 III, 1932 佐渡小材；IV，1932 佐渡二見村；10 VI, 1951 岩船郡大陭村；IV，1954 佐渡； VII, 1950 佐渡両津市； 5 IV, 1959 (早成), 30 IV, 1963 (虫幼), 29 XII, 1963 (早成), 26 III, 1965，23 III，1965 (成) 柏崎市裏浜海岸

9) Larus glaucescens ワシカモメ 1963 高田

10) Larus hyperboreus pallidissimus シロカモメ $23 \mathrm{IV}, 1954$ 新淇汒; I, 1961 佐渡

11) Larus ridibundus sibiricus ユリカモメ

7 XII, 1962 柏崎市裏浜海岸 (合成)；II，1958 作渡。以上の他にも钎録は多ん。

1) Stercorarius pomarinus トウゾクカモメ

$$
\text { Stercorariidae トウゾクカモメ科 }
$$

1949 岩船

$$
\text { Alcidae ウミスズメ科 }
$$

1) Uria alge inornata ウミガラス

II, 1953 佐渡；25 I, 1954 新潟；20 I, 1959 柏崎市上東； 6 II, 1962 柏崎市裏泜海岸 (早成)

2) Uria lomvia arra ハシブトウミガラス

I, 1926 岩船郡海府; XII, 1926 瀨波；21 XII, 1964 (忠成), 5 I, 1965 (2個体)，24 I, 1965

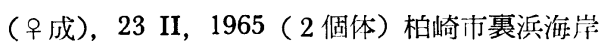

3) Brachyramphus marmoratus perdix マダラウミスズメ

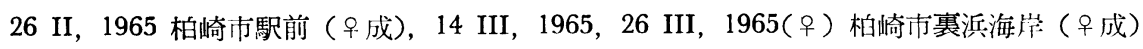

4) Synthliboramphus antiquus ウミスズメ

I, 1942 北蒲原篗网村；1946 高田；II, 1953 恢渡；15 XI, 1956 新潟市寄居町；23 I, 1959，23 I, 1960 (早成), 23 III, 1962 (ㅇ誠), 20 XII, 1962 (우成), 25 XII, 1962 (우成), 13 I, 1963 (早成), 30 I, 1963 (早成) 柏崎市裏浜海岸; 16 II, 1963 (令成) 柏崎市悪田海岸; 16 II, 1964 (早成), 9 III, 1964 (古成), $18 \mathrm{III}, 1964$ (古成), $21 \mathrm{III}, 1964$ (令成), 22 XII, 1964 (合成) 柏崳市裏浜海岸; 8 II, 1965 (令成) 柏崎市駅前; 23 II, 1965 (宁成)，26 III, 1965, 28 III, 1965 (今成) 柏崎市裏浜海岸 
5) Aethia cristatella エトロフウミスズメ

1919 柏崎；I, 1926 岩船郡上海府；25 XII, 1956 (이成), 20 XII, 1959 柏崎市裏浜海岸

6) Aethia pusilla コウミスズメ

I, 1912 柏崎；XII, 1917, I, 1918 岩船；III，1920 柏崎；II，1922 岩船；I，1926 岩船郡上海府; II 1926 瀬波；1946 高田；I，1961 杤尾市；25 II，1962，1 III，1965 柏崎市裏浜海岸

7) Aethia psittaculus ウミオウム 1919 柏崎；15 XII，1925 粟島；７Ｉ，1926 岩船郡下海府；3 I，11927 村上；23 III，1965 柏崎市

8) Cerorhinca monocerata ウトウ

I, 1940 村上； 22 IV，1954，III，1955 佐渡；16 II，1963，2 I，1964 (早成) 柏崎市悪田海岸; 28 II 1965 (合成) 他に 1 個体； 7 II, 1965 (ㅇ成), 14 II, 1965 (ㅇ成) 他に 1 個体 柏崎市裏浜 海岸

9) Lunda cirrhata エトピリカ

新潟県

以上の記録は中村 (1925), 不沢 (1956), 䳡司・池四 (1936), 黑田(久) (1958), 佐藤 (1953・1963), 千羽(元) 1955), 清棲 (1954), 大河津公民館 (1956), 千羽(晋) (1961), 風間・千羽 (1964・1965), 風間 (1963) の報告のほかに，風間辰夫氏，本間隆平氏などので教示によってまとめたものである。

Table 1. 柏崎海岸海鳥整死例 (1959 1965)

(Records of drifted sea birds on Kashiwazaki coast, 1959-1965)

\begin{tabular}{|c|c|c|c|c|c|}
\hline \multirow{2}{*}{$\begin{array}{ll} & \text { Species } \\
\text { Pterodroma } & \text { hypoleuca }\end{array}$} & \multicolumn{3}{|c|}{ Date } & \multirow{2}{*}{$\begin{array}{l}\text { Sex, age } \\
\text { 今ad. }\end{array}$} & \multirow{2}{*}{$\begin{array}{l}\text { Estimated days after death } \\
\qquad 2 \sim 3\end{array}$} \\
\hline & 17 & $\mathbf{x}$ & 1959 & & \\
\hline \multirow[t]{2}{*}{ Calonectris leucomelas } & 4 & iii & '64 & 우 ad. & $1 \sim 3$ \\
\hline & 18 & iii & '62 & $\hat{o} \mathbf{a d}$ & $0 \sim 3$ \\
\hline \multirow[t]{2}{*}{ Gavia arctica viridigularis } & 28 & $\mathrm{i}$ & '63 & $\hat{\delta}$ ad. & $1 \sim 2$ \\
\hline & 1 & iv & '64 & 우 ad. & $3+$ \\
\hline \multirow[t]{5}{*}{ Gavia stellata } & 24 & $\mathbf{i}$ & '65 & 우 ad. & $0 \sim 1$ \\
\hline & 13 & ii & '64 & 우 ad. & $0 \sim 1$ \\
\hline & 9 & iii & '63 & 우 ad. & $0 \sim 1$ \\
\hline & 18 & iii & '64 & 今ad. & $0 \sim 1$ \\
\hline & 22 & $\mathrm{iii}$ & '61 & 우 ad. & $0 \sim 2$ \\
\hline \multirow[t]{4}{*}{ Rissa tridactyla policarıs } & 16 & ii & '64 & 우 juv. & $2 \sim 4$ \\
\hline & 23 & $\mathrm{iii}$ & '65 & $? ? ?$ & $3+(4$ birds $)$ \\
\hline & 26 & iii & '65 & ? ? juv. & $2 \sim 3(4$ birds $)$ \\
\hline & 28 & $\mathrm{iii}$ & '65 & 令令 ad. & $2 \sim 3(6$ birds $)$ \\
\hline \multirow[t]{3}{*}{ Larus schistisagus } & 28 & $\mathrm{iii}$ & '63 & 우 juv. & $3+$ \\
\hline & 28 & $\mathrm{iii}$ & '65 & 우 ad. & $2 \sim 3$ \\
\hline & 21 & xii & '62 & 우 ad. & $3+$ \\
\hline \multirow[t]{4}{*}{ Larus canus camtschatschensis } & 6 & $\mathrm{i}$ & '65 & 우 ad. & $0 \sim 1$ \\
\hline & 23 & $\mathrm{iii}$ & '62 & $\hat{o}$ ad. & $3+$ \\
\hline & 26 & $\mathrm{iii}$ & '65 & $? ?$ & $3+$ \\
\hline & 16 & iv & '63 & 우 ad. & $3+$ \\
\hline Larus crassirostris & 23 & iii & '65 & ? ad. & $2 \sim 3$ \\
\hline
\end{tabular}




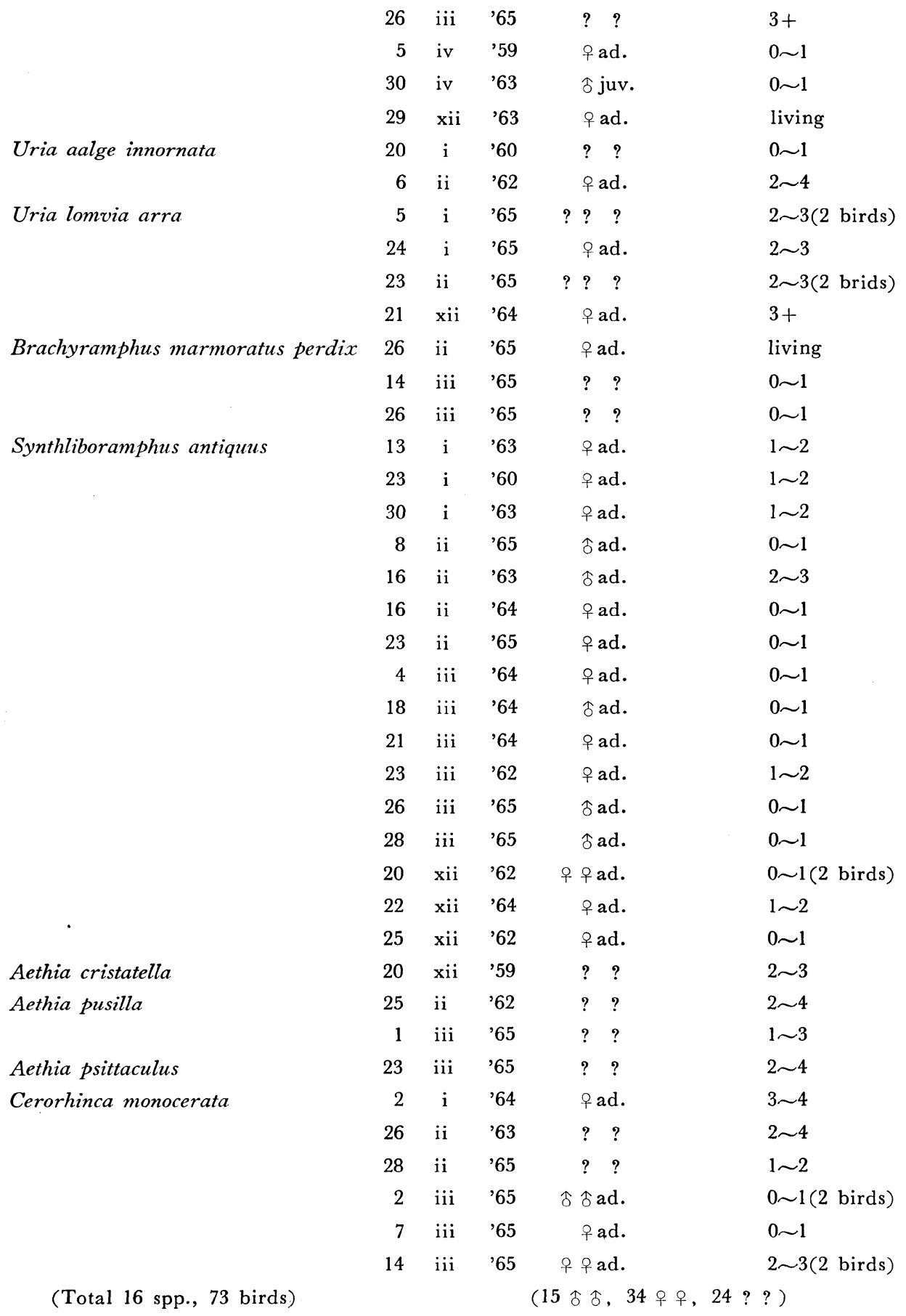




\section{整死海鳥記録とその要因}

新潟県は海に接した部分は広いが，海鳥類の斃死体の漂着するのは，ほとんど柏崎市一帯の 海岸線である。これらの獘死体は死亡後数日を経たと思われる爫のや死亡直後と推定されるも

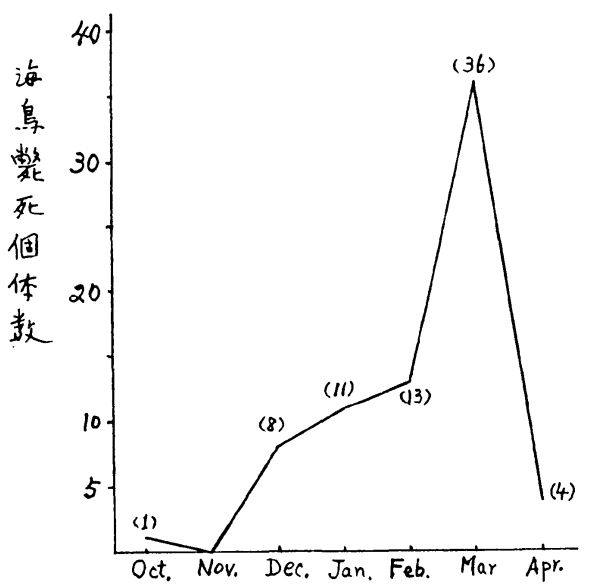

Fig. 1. 柏崎海岸の海鳥紫死発見月別偳体数
のなど，多種多様である(Table 1.)。これらは発 見された時期によって概略一致した傾向が見られ笍 敗の進んだものは必ずしも気温の高い時期であると はいえない。秋死の時期は第 1 図に示す如く, 10月 から4月にわたるが 12 月 ( 8 例)，1月 (11例)， 2 月(13例), から 3 月(36例)に急増し 4 月 ( 4 例) には 急減して打り, 冬の海の最も荒れる季節である。ま た, 秋死鳥の性別は雄15, 雌34(不明24)で雌が倍以 上となる。

これらの海鳥類の大量整死の原因を, 柏崎市の気 象資料をりとに検剖してみた。

\section{(イ) 温度との関係 (Fig. 2)}

1 日の温度差について4年間の平均と推定斃死日 の平均を比較すると, 2 月, 3 月を除いては $2 \sim 3^{\circ} \mathrm{C}$ くらいの差が見られる。12月，4月の整死には，温度差の大小が影響しているように推察され るが，総体的には明確な結果とはいえない。

平均気温は, 弊死数との間に, ほとんど差はなく，その時の平均気温には原因はなさそうであ る。
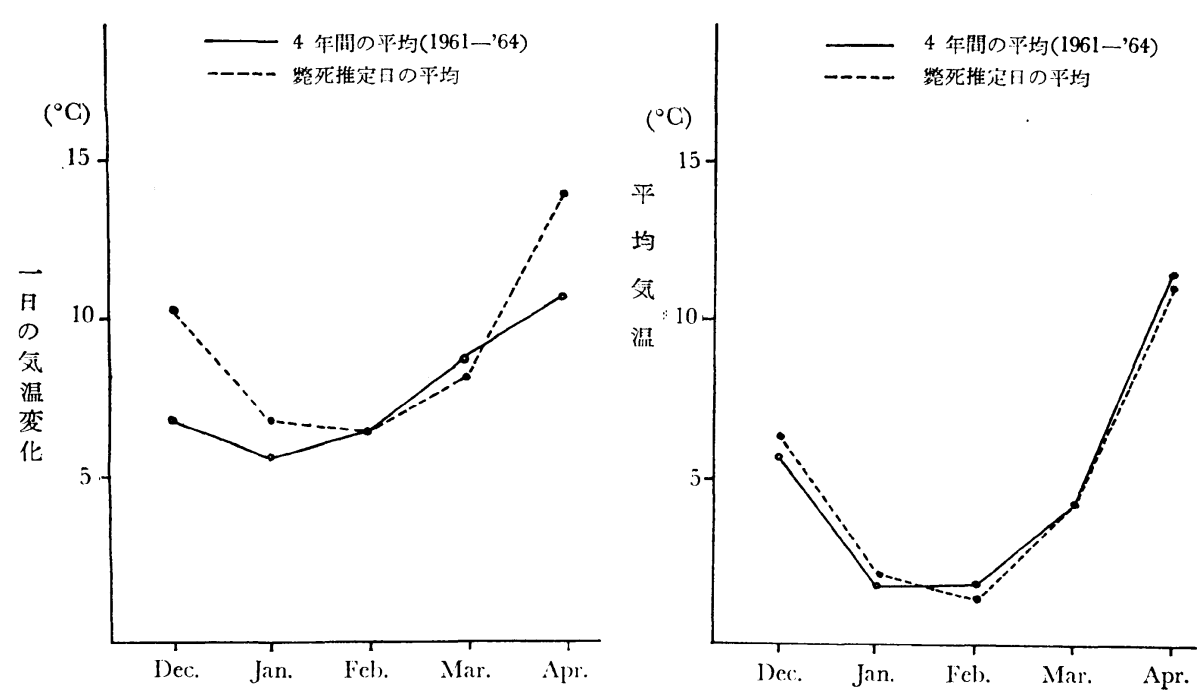

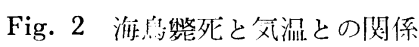




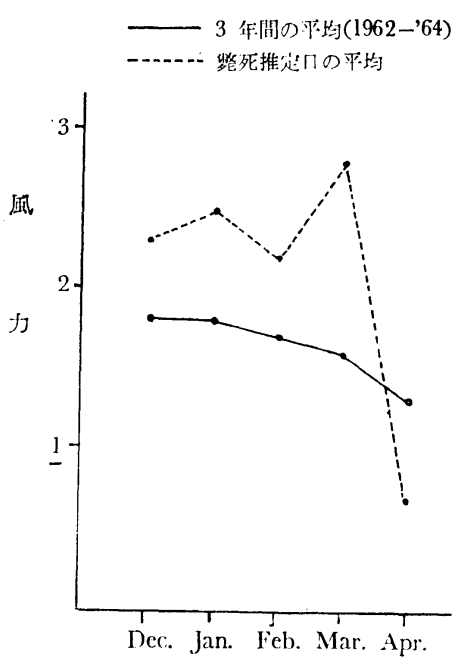

Fig. 3. 海鳥紧死と風力との関係

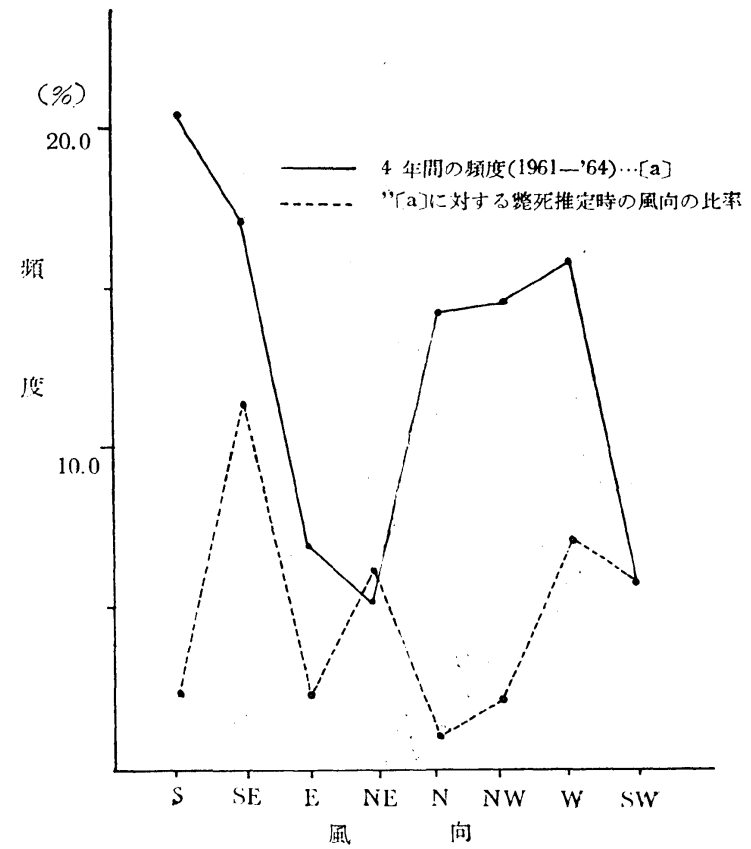

Fig. 4. 海烏眥死と風向との関係

（ロ）風力亡の関係 (Fig. 3)

獘死鳥発見時の風力が， 3 年間の平均を上まわっている。風力 3 は 4 $8 \mathrm{~m} / \mathrm{sec}$. の風速であ るが, この他, 気像朾ビューフォート風力段階表によると, 風力 3 では波高は $0.6 \sim 1.0 \mathrm{~m}$ とな り，4では $1.0 \sim 1.5 \mathrm{~m} ， 5$ では2.0〜2.5mになるとされている。したがって，風力が慗死の一 因として考えられるが，風力とともに，その時生ずる海上の波高もあわせて考える必要があろ 弓。

\section{（八）風向之の関係 (Fig. 4)}

平均風向（1961〜'64 の各 12〜4 月の平均）と，それぞれの風向に対する整死頻度を見ると き, SE. NE. W. SW. などの風向の時に, 高い比率で慗死の現象が見られる。しかしここの風 向も総体的には余り整死のための原因とは考えられない。

川口，丸茂 (1964) の駿河湾に抢けるハシボソミッ゙ナギドリの例によると，気象条件が海鳥 類の活動を不活発化させるとしているが，新潟県柏崎市海岸における整死現象も，同じような 傾向がうかがえるのである。

以上のようなことから獘死鳥になって発見される原因は，（1）1日の気温の高低差の大きい 時,（2）風力と風力にともなって生ずる波高の大さ，(3)東 $(\mathrm{E})$, 西 $(\mathrm{W})$ の風向などがあげら れるが，気象資料の連続的な結果を見ると天候の変化時に多いことがあげられる。

しかし，これらの原因が単独で生じた場合には要因とはならないが，複合して生じた時に海 鳥類の活動を不活発化し, 多くの斃死鳥に見られるような飢餓の状態に掞いやり，ついには笅 死に至らしむ百子のと推定されよう。 
この他, 重油による污染で活動を阻害されるもの, ゴム輪などの異物の飲下での空息死など, 直接的な原因もある。これは料山（1922）による福井県下の報告例でも知られるが，気象条件 も重要な原因であるとしてのべている。

\section{整死例から見た海鳥の季節的分布海面の推定}

先に記したように，新潟県内の海岸では，枯崎市海岸に集中して整死鳥の漂着が見らる。

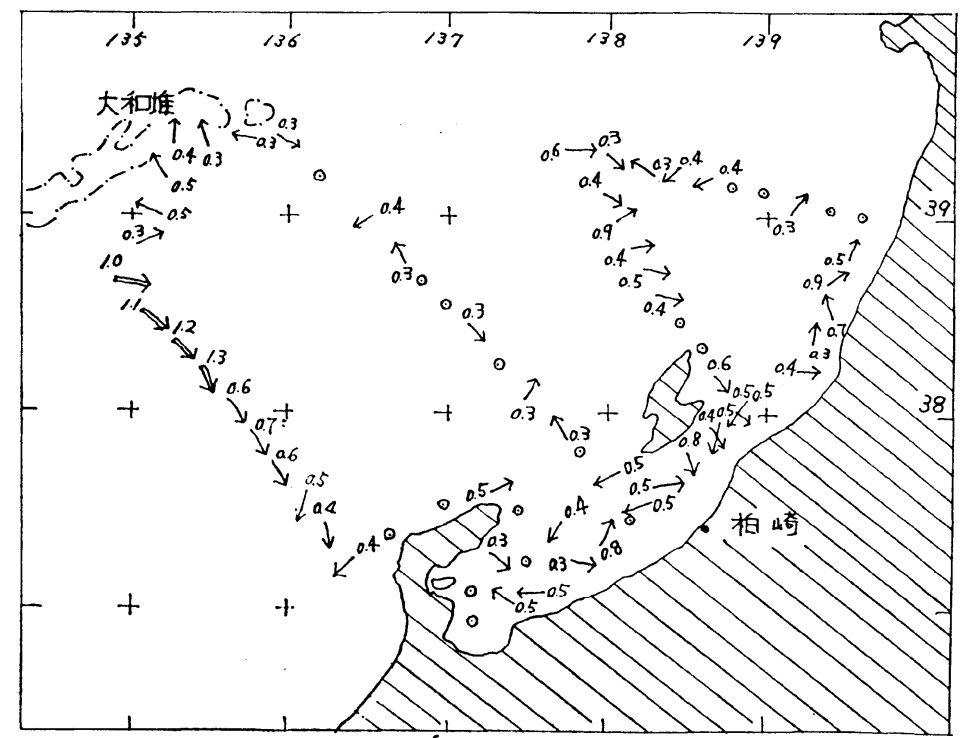

Fig. 5. 11 万の海流図

注：流速 Kt

(第九管区海上保安本部 钼测)

Fig. 6. 3 月の海流闽

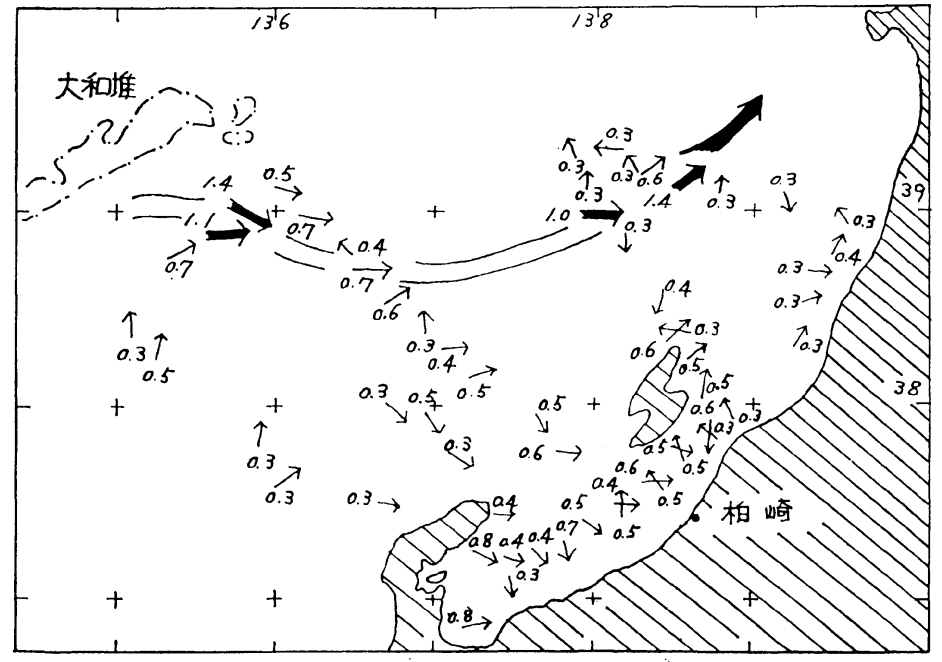

注：流速 $K t$

（第九管区海上保安本部 镜測） 
この原因の第 1 として11月から 3 月頃で, 日本海の海流の方向が，この地域に集中してること から推定できる。

海上保安庁抢よび日本海区水産研究所の海流測量結果では, 沿岸部に打ける調査の粗密のち がいはあるが，いづれも11月から 3 月まで, 柏崎海岸に向いている流向が知られる。

この地域に向う流速は 0.5 0.8kt. で, 1 日約 $45 \mathrm{~km}$ となる。この流速, 流向 (Fig. 5,6) と, 繁死鳥の鮮度から逆算した獘死推定日（Table. 1) とを検討するとき，11月から 3 月まで の，この付近での海鳥類の生息分布を推定できるのではないかと思われる。

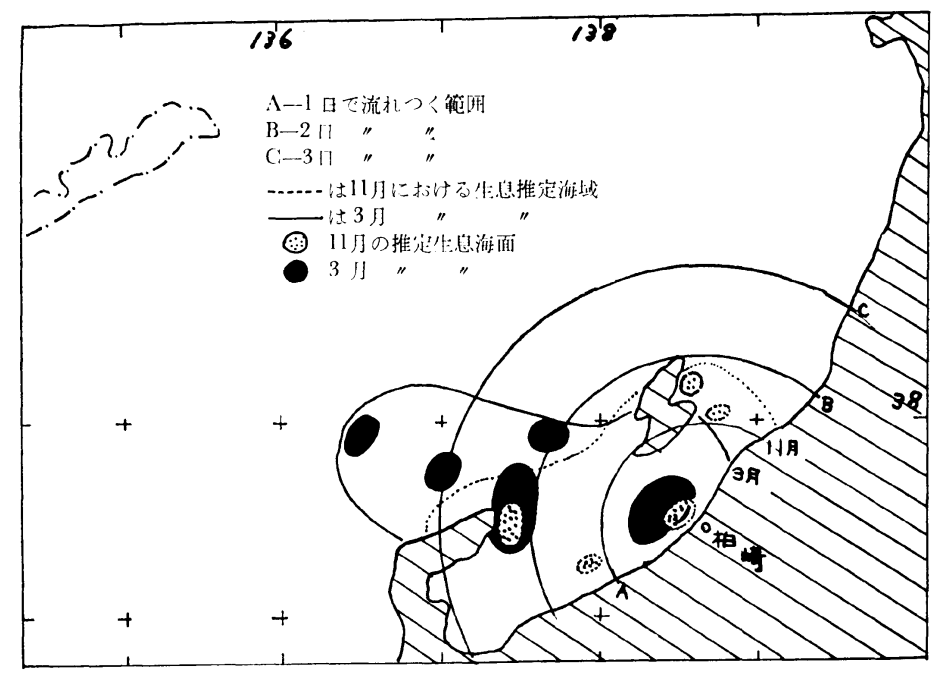

（この四は淤流四の調柋地点をもとに流速流向を逆にたどって求めた。）

Fig. 7. 11〜3 月の海鼠の推定生息海面

その結果求めたのが Fig. 7 に示したものである。11月では地域も海岸線に近い範囲で, $38^{\circ} \mathrm{N} \cdot 139^{\circ} \mathrm{E}$ (両津湾北方地域) 加 $37.5^{\circ} \mathrm{N} \cdot 137.5^{\circ} \mathrm{E}$ (珠州岬東方海域) を結ぶ地域内で, しかも, 海岸線に近い地域に集中しているようである。 3 月では $38^{\circ} \mathrm{N} \cdot 138.5^{\circ} \mathrm{E}$ の地域から $38^{\circ} \mathrm{N} \cdot 136.5^{\circ} \mathrm{E}$ (軸倉島海域) の比較的海岸線からはなれた地域になる。

このように 3 月と 11 月で生息海面の地域が異っているが, これは多分, 海鳥類の渡り時の移 動に関連しているのではないかと思われるが，確かなことは判らない。

また，新潟県では海上が荒れた時にのみ内陸の河川，湖沼え海鳥の飛来が見られることか ら, 多くは海上生活をするものであろう。それは, 冬季の分布海域を地形的に胃ると, 佐渡ガ 島と能登半島が季節風, 波浪の防波堤的な役割りをしているものと考えられないだろうか。事 実外佐渡と内佐渡では海上の荒れ方がいちぢるしい相跍を见せていることからも推察されるの である。

10月から 3 月までの各月に兄られる分布海域の変化を胃たが，まだこれといった原因を求め ることはできなかった。これからは黒四展久先生からご教示頂いた, 外洋との気象条件の差, 飭の分布，海の荒さの变化，水温分布などの閵係を調べて最終的な結果を求めたい。 


\section{むす び}

新潟県で発見された獘死海鳥をもとに，海鳥類の目録，整死の原因，冬季の海鳥の分布海面 の推定を試みてみたが，1965年 1 月から，また，本年 9 月にはすでに渡り鳥の記録，整死鳥の 発見などが見られて抢り，今後さらに資料を収集し，改めて報㸃したい。

本稿を終るにあたり，で校閲とで教示を賜わった黒四长久博士（山階鳥㹰研究所），貴重な资料の提供を 得た風間辰夫氏 (柏崎市中田駐在斦), また, 海流などの資料の収集に際し, ご䚮力, で教示を得た大森康 正博士（新潟大学医学部)に深葆な㴬意を表します。

\section{文献}

千羽 晋示 1961. 新潟県の鳥類につんて 長岡市立科博研報 2

石沢 慈鳥 1956. 新潟県産鳥類につんて鳥獣集報 15(1)

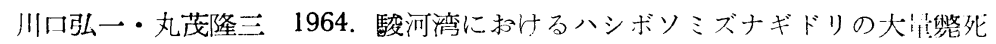

山階烏研城 4(2)

風間 辰夫（投稿中）海鳥の大星整死 岛

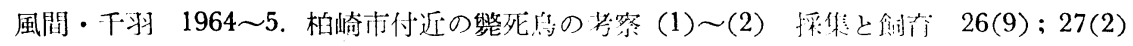

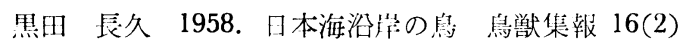

数山徳太郎 1922. 福井県下の海舀整死 動推 34(405)

中村 正雄 1925. 新潟県天産誌 $704 \mathrm{pp}$.

小沢敬次郎 1964. 東海道沖命に扔けるハシボソミッ゙ナギドリの人员死について

山階鳥研趣 4(2)

\section{The sea-bird wreck on the coast of Niigata Prefecture}

\section{Shinji Chiba}

Between October and April, many sea-birds have been found dead on the beach on Niigata coast concentrated in Kashiwazaki area. This part is south of Sado I. and east of Noto Peninsula and owing to this situation, winds and sea currents are very complicated. Since 1959 to 1965, 16 species, 73 birds were collected and the correlations with temperature and winds were considered (possibly positive with day variation in temperature and wind velocity and consequent waves). From the sea currents and the state (freshness) of drifted birds, the distribution of these birds in March and November was estimated.

National Park for Nature Study, National Museum of Science, Shiba, Minato-ku, Tokyo 